\title{
Tocqueville, Pascal, and the Transcendent Horizon
}

\author{
ALEXANDER JECH
}

\begin{abstract}
This article traces the contours of Pascal's influence on Tocqueville's understanding of the human condition and our appropriate response to it. Similar temperaments lead both authors to emphasize human limitations and contingency, especially our mortality, our ignorance of the most important subjects, and the effects of historical contingency on human nature, and both represent the complex internal dynamic of human nature in terms of the interplay of "angel" and "brute." They disagree over the power and significance of human action. Whereas the motif of human weakness is fundamental for Pascal, Tocqueville repeatedly affirms that, under the right conditions, human beings are "powerful and free." Beginning from Pascalian premises, and endeavoring to be more faithful to some of those premises than Pascal himself was, Tocqueville aims to illuminate the possibility of an amelioration of the human condition through a "new political science" that redeems the political realm without divinizing it.
\end{abstract}

Most students of Tocqueville know of his remark, "There are three men with whom I live a little every day; they are Pascal, Montesquieu, and Rousseau." 1 Pascal is considered a religious rather than a political philosopher and is not often invoked in discussions of politics, so the influence of the other two is more obvious and more widely commented on. Yet Pascal's influence is as profound as theirs, and although Tocqueville made a careful study of Pascal's elegant yet natural literary style, it is not merely stylistic. ${ }^{2}$ When we examine Tocqueville's understanding of human existence and seek to get a sense of

Alexander Jech is professor of philosophy, University of Notre Dame, 100 Malloy Hall, Notre Dame, IN 46556 (ajech@nd.edu).

I would like to express gratitude to Michael Zuckert, Roger Knights, and the three anonymous referees for their helpful advice in the writing of this article.

1. Correspondence of Alexis de Tocqueville and Louis de Kergorlay, Oeuvres complètes (Paris: Gallimard, 1977), 13:418.

2. See the article by Kergorlay titled "Etude Littéraire sur Alexis de Tocqueville," in Le Correspondant, April 1861 (see annexe in Oeuvres complètes, 13:352-63): “As [Tocqueville] approached maturity, he attached himself by preference to other masters, to none other than

American Political Thought: A Journal of Ideas, Institutions, and Culture, vol. 5 (Winter 2016).

2161-1580/2016/0501-0005\$10.00. @ 2016 by The Jack Miller Center. All rights reserved. 
what we might call his own "religious sensibility" and his conception of the shape and limitations of human life, we constantly find him wrestling with Pascal, dialectically engaged with Pascal's arguments and positions, and developing his own more social, more historical, and more political conception of the human condition.

Since Diez del Corral's "Tocqueville et Pascal," there have been several attempts to understand Pascal's influence on Tocqueville (Corral 1965). The new critical edition of Democracy in America edited by Eduardo Nolla and translated by James Schleifer is helpful in making some of the most patent connections clear to the reader. The most notable and sustained of these studies is Peter Lawler's The Restless Mind: Alexis de Tocqueville on the Origin and Perpetuation of Human Liberty, to which my account owes something, but I regard his book as making Tocqueville too indebted to Pascal and not doing justice to the social and political aspects of Tocqueville's thought. By and large, however, Tocqueville scholarship has not made much of Pascalian influence, and so readers may wonder just to what extent the seventeenth-century scientist, Jansenist, and polemicist shaped the convictions of the nineteenthcentury statesman and political theorist.

Fundamentally, what Tocqueville and Pascal share is a temperament open to certain experiences of the sublime, on the one hand, and aware of human limitations and contingency, on the other. This temperament leads them to endorse similar kinds of principles, although they do not always interpret the same experiences in the same way and do not always draw the same conclusions from them. My goal here is to identify the exact points on which Tocqueville and Pascal agree or disagree regarding the human condition and thereby to illuminate why they draw different conclusions on that subject.

On a wide number of points regarding the importance of mortality, ignorance, and the structure of human nature, there is significant agreement between the two thinkers. I shall discuss each of these points in what follows. Moreover, one great difference between Pascal and Tocqueville grows out of a point of agreement. Both believe that what different people count as "human nature" and as "justice" at any given time is heavily influenced by custom and history. Pascal addresses such themes in a variety of ways, and in fragment 159 he toys with the radically historicist idea that, our true nature having been lost in the Fall, we are now custom all the way down. Pascal's reflections on the power of custom to shape human sentiments and behavior, however,

Pascal for the very depth of the language, to Voltaire for the ease and the art of lightening the style.” 
are not developed in a systematic way. Tocqueville, on the other hand, treats the historical malleability of human nature as one of his primary problematics. His science of social state functions to unify the "two distinct humanities" of "democratic man" and "aristocratic man" and to subject such historicism to a rule (Democracy in America 2.4.8; Tocqueville 2010, 1282; see also Zuckert 1993; Jech 2013). ${ }^{3}$ His thought is therefore more social and more political than Pascal's.

The most important difference between them concerns their relative estimates of human power and the significance of human action. The motif of human weakness is an important part of Pascal's analysis of the human condition. "What astonishes us most," Pascal says, "is that everyone is not more astonished at his own weakness" (frag. 67). One finds Pascal returning to this theme in fragments $62,67,130,182,184,240,249,540$, and 643, among others. Human action is incapable of ameliorating the afflictions associated with the human condition and is engaged in primarily as a means of avoiding honestly facing those afflictions. For Pascal, action is frequently no more than a form of distraction or diversion (frags. 168 and 171); it is as if humanity dwelled in a doomed valley, afflicted by severe and crippling ills that will eventually destroy us, while our only cures lay beyond the impassable peaks closing us in. To solve the human condition would require transcending it, a task that requires equally transcendent power.

Tocqueville, on the other hand, repeatedly affirms that, under the right conditions, human beings are (in a turn of phrase one cannot imagine finding in Pascal) "powerful and free" (2.4.8, Tocqueville 2010, 1285). Despite agreeing with Pascal that human greatness lies entirely "in the soul," he modifies this idea so that its significance is that human greatness is especially present in action. Tocqueville arrives at this conclusion from Pascalian premises. In fact, in a crucial respect, he makes these premises more internally consistent than Pascal had done. Without denying Pascal's otherworldly conclusions, Tocqueville affirms a very different orientation to the here and now-to the temporal and finite realm. He opens up the possibility that engagement with the things of the world can amount to more than vanity and distraction. Tocqueville's statement that the Americans have "successfully blended ... and marvelously combined" the "spirit of religion" and the "spirit of liberty" is indicative of a concern with providing an amelioration of the human condition via a harmonization of the two aspects of human nature in the form

3. Citations from Democracy in America refer to the bilingual critical edition (Tocqueville 2010). Citations from The Old Regime and the Revolution refer to Alan Kahan's translation (Tocqueville 1998). Citations of Tocqueville's letters are from Tocqueville (1985). 
of a "new political science" that redeems the political realm without divinizing it.

\section{PASCAL'S PREMISES}

Nietzsche, no friend to Christians, wrote in a letter to his friend Georg Brandes that Pascal was the "only logical Christian" and averred that he had learned "an infinite amount" from him (Nietzsche 1996, 327). Such testimony should lead us to expect to find a very powerful analysis of the human condition in Pascal's works, an analysis that forms the basis of his conclusion that the only solution to humanity's woes is supernatural and otherworldly and never to be achieved by human action in this world. Yet, for all the clarity and logical rigor we find in his published papers, when we examine the Pensées, the work where we find Pascal's observations and analysis of the human condition, we encounter an unfinished work of cobbled-together fragments, whose pages shine with brilliant observations but which sprawls out with no obvious order, in apparently disorganized and contradictory array. Is there a deeper logic here, or even a coherent conception of human life?

The reception of Pascal's work (especially the history of responses to the now-eponymous "Pascal's Wager") demonstrates the value of exercising patience on this point, for it is Nietzsche who appears to have had the more accurate sense of the Pensées' aphoristic fragments. ${ }^{4}$ Time has led to a sharper and subtler understanding of what Pascal is up to. When Pascal's writing appears obscure, one must be careful not to assume that the difficulty is in his thought; instead, one must first seek to uncover the logic behind it. Here I will try to reconstruct the main lines of his conception of the human condition, especially those aspects with which Tocqueville was most engaged. I will do this first by delineating a set of "premises" Pascal develops through close observation or analysis of human behavior and then, in the next section, by turning to the conclusions that he draws from these premises.

The first premise of Pascal's argument is that the human desire for happiness is universal. As he puts it, "[man] wants to be happy, he only wants to be happy, and cannot not want to be happy" (frag. 166), and "[happiness] is the motive for men's every action, even those who are going to hang themselves" (frag. 181).

4. See Hacking (2006) for a good example of how the development of probability theory, on the one hand, and a better understanding of Pascal's manuscript, on the other, have led scholars to a much subtler appreciation of the precise nature and function of Pascal's Wager. 
1. All human beings necessarily wish to be happy, and all other desires are subordinate to this wish.

This is our dearest desire; nonetheless, we suffer from a deep lack of clarity regarding the nature of happiness. Happiness consists in peace or rest, while we consistently seek it out through activity (frag. 166). We do not understand happiness well because we intuitively or subconsciously recognize that our condition makes its achievement impossible. When happiness is impossible, our happiness is best served if we avoid dwelling on its impossibility, because doing so would make us even worse off and more miserable than before: "men have decided for their own happiness not to think about it" (frag. 166).

Tocqueville agrees that we all desire happiness, although he does not espouse the very strong, rather "classical" description of this desire expressed in Pascal's premise. He appears to hold a weaker version of the premise instead. In Democracy in America Tocqueville states that "personal interest" is the "only fixed point in the human heart" (1.2.6, Tocqueville 2010, 391), and elsewhere he says that all human beings possess an "ardent passion" for happiness (Tocqueville 1985, 63), but he also denies that all our actions are performed for the sake of self-interest (2.2.8, Tocqueville 2010, 921). "Interest" is not quite what Pascal means by "happiness," but we can settle here by saying that Tocqueville agrees at least that we all pursue happiness and desire it. $\mathrm{He}$ also agrees that happiness is not truly possible (Tocqueville 1985, 63).

Now, why does Pascal think that our happiness is so elusive, and so poorly understood? Pascal is an antisystematic thinker. He distrusts the vanity involved in system building, which serves the pride of the philosopher (frag. 175). Human nature consists of "two different natures" (frag. 144), both "instinct" and "reason," "passion" and "thought," "greatness" and "baseness," the "angel" and the "brute," combined in a confused mixture we cannot comprehend (frags. 164 and 230). It is dangerous to understand only one of these: we must understand both our "greatness" and our "baseness" to think and live as we ought (frags. 153 and 513). Yet philosophers for the most part have tried to reduce human beings into one of these alternatives: "Some wanted to renounce the passions and become gods, the others wanted to renounce reason and become brute beasts. But neither group succeeded" (frag. 29; see also Dreyfus 2012). From the Platonists, Stoics, and Epicureans of antiquity down to Descartes and Hobbes in Pascal's own time, philosophers were guilty again and again of oversimplifying the mixture that is humanity in order to render it more theoretically tidy and unified. They unknowingly agree with Dostoevsky's Dmitry Karamazov that human nature is "much too prodigious" and should be "cut down to size" (Dostoevsky 1994, 136). 
Pascal refuses either simplification; human nature contains both "baseness" and "greatness," and we are thoroughly contradictory (frag. 230). Thus,

2. All human beings are a mixture of a rational nature and an animal nature, each with its own principles.

He also denies that we can, or should aim to, become wholly one or the other. We can never escape the needs or properties associated with the half we try to suppress, and the attempt to do so only corrupts the aspect we pursue: "Man is neither angel nor brute, and the unfortunate thing is that he who would act the angel acts the brute" (frag. 358). Human happiness requires that both sides of our nature be fulfilled, not just one or the other. We fail at achieving happiness when either the brute's or the angel's desires are denied (frags. 110 and 166 ) or when the war between these two aspects prevents us from finding any repose (frags. 29 and 168).

3. Human happiness requires fulfilling both our rational and our animal nature and harmonizing these with each other.

Tocqueville not only accepts premise 2 , the mixture principle, but adopts Pascal's language as well, referring to humanity as being divided between the "angel" and the "brute" (2.2.16, Tocqueville 2010, 963). Tocqueville further accepts that each of these elements has its own distinct needs and desires (2.2.12, Tocqueville 2010, 940;2.2.15, Tocqueville 2010, 956). Thus, Tocqueville also accepts premise 3 . It is unhealthy for humanity to live too much as angels or as brutes. Tocqueville noted that the colonists in the West Indies succumbed to the temptations of bestiality and suffered for it (1.1.1, Tocqueville 2010, 38), but he also pointed out that those who live too much within the realm of thought also suffer for it (2.1.10, Tocqueville 2010, 781-82), tacitly chiding Pascal for failing to live by his own principles. The wish to satisfy only the angel or only the brute is a self-destructive urge that legislators ought to combat (2.2.15, Tocqueville 2010, 956). One also thinks of his mixed judgment on the leading figures of the French Revolution, those extraordinary figures who understood the theory of politics much more than they understood true statesmanship, who excelled more in "genius" and in "conceiving vast plans" than in "common sense" and the achievement of "great tasks"and who consequently fell short of "true glory" (The Old Regime and the Revolution 1.3.8, Tocqueville 1998, 246).

Unfortunately, we are incapable of fulfilling the desires of either aspect of human nature. The rational aspect of our nature desires to know the truth but is trapped between ignorance and knowledge (frag. 230). We cannot help 
wanting to know the truth about human existence, but its accomplishment is impossible (frag. 110). Human reason is calculative, moving from premises to conclusions, and perfect in itself when its method is sound (Pascal 1995, 19697), but incapable of securing its first premises, which it acquires from "nature" (Pascal 1995, 194). What we regard as nature, however, is subject to custom and frequently misleads us (frag. 164). It is subject to the "uncertain balance between truth and pleasure ... in the deepest interior of a human being," in such a way and to such a degree that a person rarely knows which he or she is following (Pascal 1995, 195). The attempt to use our finite intellect in order to comprehend an infinitely great and infinitely divisible universe disorients our reason, which requires a resting point (frag. 230). For Pascal, human science necessarily includes a "void" within it, "at its foundation" (Khalfa 2003, 133). Moral knowledge is incomparably more important to us than scientific knowledge (frag. 57), but the difficulty, or impossibility, of knowing ourselves or our true nature makes it even more elusive (frags. 230 and 576). We are unsure even of how far our ignorance goes, because neither skepticism nor dogmatism can be established (frag. 164). The lack of a fixed point leaves us with the realization that for all reason can show us, every aspect of human life is contingent and accidental. The kind of cosmic order that the philosophers have sought, which would give us a clear sense of human identity and purpose, is entirely absent; the universe is "silent" (frag. 229).

Can one live well by embracing the brute? Pascal does not take this option seriously, or perhaps does not take himself to be addressing those who would seriously consider pursuing a life like this. We cannot eliminate the angel, the rational aspect of human nature, but we can make it serve the brute by devoting it to searching out the means for securing the brute's desires and existence. In Tocqueville's phrase, the angel is capable of teaching the brute and showing it how to meet its needs, even to the point of constructing a sort of morality that secures our brutish desires. Even in this role, the rational side of human nature shows its greatness (frag. 138). But the rational aspect of human nature distorts the brute's simple desires: the interaction of the rational and animal aspects of humanity produces the imagination, which renders the desires of the brute fantastical, unlimited, and incapable of satisfaction (frag. 78). Furthermore, reason reveals to the brute that we must die. Death undermines contentment, for it is the most inescapable of our ills and our knowledge of its inescapable and unpredictable arrival is itself an enormous evil (frag. 681). Knowledge of death is so miserable that we require constant diversion or distraction to escape from its misery (frag. 166).

Furthermore, the desires rooted in the two aspects of our nature conflict with each other (frag. 514). They draw us in different directions and require 
different things of us; the difficulty of reconciling them is what has led philosophers to their inaccurate simplifications of human nature (frag. 29). The two aspects of ourselves do not fit together well; taken as a whole, man is a monstrous, incomprehensible being (frags. 163 and 164). Pascal therefore concludes,

4. We are incapable of fulfilling or even harmonizing the desires natural to human nature.

Tocqueville largely accepts premise 4 . He understands mortality as an evil we innately desire to escape, which impinges especially on our desire for material things and therefore conflicts with the desires of the "brute" (1.2.9, Tocqueville 2010, 482). He is aware of the power of general ideas but is also aware of the cost associated with them (2.1.3, Tocqueville 2010, 727). He believes that we are incapable of achieving either happiness or knowledge; Tocqueville says that we have an innate desire to engage in "the search for absolute, demonstrable truth," but pursuing this "impossible" quest succeeded only in throwing him into "a horrible state," "the unhappiest time of his life." The "inextricable doubts" he encountered so disoriented him that he felt "the floor tremble under his feet" and saw "the walls that surround him move." Despite our immense desire to know and to understand our own existence, our lack of certainty regarding "the immense majority of points that it is important for us to know" is "one of the most inflexible laws of our nature" (Tocqueville 1985, 64). Fundamentally, we do not understand our place in the universe or the significance of our existence; we experience our lives as contingent, and our reason is sufficiently weak that we cannot live without dogmatic beliefs (2.1.2, Tocqueville 2010, 712-15). Pure thought is too difficult for us.

Human beings therefore occupy an unpleasant position. Can they ameliorate or, better, correct this condition? Can the being nature left in painful perplexity overcome its condition by its own efforts at reform and enlightenment?

Pascal's answer is a firm "No": the causes of human misery escape human control. Our misery is matched by our weakness. The nature of our ignorance is itself a cause of our remaining in ignorance; our ignorance is not simple, so that our ignorance of a moral standard itself prevents us from identifying the moral standard. "We need a rule" to determine which starting point to begin from, but "reason is pliable in either direction," and so "there is no rule" (frag. 455). We have no power to overcome human mortality. And no one has yet found a means of making the passions and reason live with each other, nor is it clear how someone could. 
5. We lack the power to change the human condition so as to make it possible to fulfill the desires natural to human nature or to harmonize our two aspects.

The wretchedness of the human condition, combined with our powerlessness to make it anything else, lies at the root of the great restlessness that marks human nature. According to Pascal, our desire to be happy and our incapacity to become so force us to continually engage in an absurd attempt to undo what cannot be undone, the corruption of human nature. The only remedy available requires turning to God for help, which is contrary to our passions. Therefore, we "doggedly refuse to face our misery" (Kolakowski 1995, 133) and seek distractions instead.

Does Tocqueville agree? In a pessimistic mood late in life, he remarks that "this singular being we call man" has been "granted just enough enlightenment to see the wretchedness of his condition but not enough to change it" (letter to Bouchitte, January 8, 1858, as quoted in Lamberti 1989, 157). But this is not his dominant mood, as we will see in a moment. First, however, let us see the conclusions that Pascal draws from these premises.

\section{PASCAL'S CONCLUSIONS}

Pascal, we sense, is not an optimist about the human condition. From his premises he concludes,

C1. Human beings are necessarily wretched and miserable beings.

We are wretched because we lack happiness; this wretchedness is necessary because we lack the power to seriously change the conditions that prevent our happiness.

Where does this wretchedness come from? According to Pascal, we were created with another nature but have fallen from that nature, and we now live with the consequences of inheriting a corrupted form of humanity, "like a fruit bred from a rotten seed" (Pascal 1995, 222). Our "unsatisfied desires for certainty, happiness, and rest" point us back to a state of perfection we have lost (Lawler 1993, 76). According to Pascal, this is the only, or at least the best, explanation for humanity as we find it, and Christianity alone provides a philosophy that makes sense of our contradictory nature (frag. 690).

$\mathrm{C} 2$. The reason why human beings are wretched and weak is that human nature has been corrupted from its original form. 
It is natural to then ask, can we never escape or improve this condition? Pascal's answer is that we ourselves can never improve this condition (frag. 67); it can, however, be improved by another-that is, by God. The natural means at our disposal all fall short. However, supernatural grace, of the kind Pascal experienced firsthand in "the night of fire" and recorded in the "Memorial" (Pascal 1995, 178), has the power to change human nature. In this life, the change is partial, although Pascal argues that saints, even in this life, are happy (frag. 389). But even saints remain weighted down with corruption until the resurrection of the dead. A full cure and harmonization of human nature will not be achieved until then.

Pascal, then, argues that only a transcendent power could cure the human condition. Moreover, because our malady must be healed by grace and not by us, there is nothing in the realm of action, within the near horizon, that can ameliorate our condition. One can train the body, the "automaton," so that it is accustomed to the ways of grace, but without grace this offers little help regarding the fundamental ills of human life. We can and should seek grace, but we cannot "win" it or perform any action that would overcome these ills. Thus,

C3. We are capable of no form of action that could cure or significantly ameliorate human wretchedness and weakness.

C4. Human wretchedness and weakness can therefore be cured only by receiving supernatural grace from a transcendent source, that is, God.

For Pascal, then, the human end is, in principle, unachievable by action and received only by grace. His conclusions drain the political realm of its significance: rather than being a domain in which to manifest the human telos, its primary significance is instead to contain the sinful self-love of individuals, which, each conflicting with every other, must be subjected to force in order for any peace to exist at all (frags. 119 and 135). Even the classical authors, according to Pascal, knew better than to ascribe any significance to action and politics. Their political theories were created "to provide rules for a madhouse" and "connived with [rulers'] delusions in order to restrain their madness to as mild a form as possible" (frag. 457). "The proper function of power," Pascal says, "is to protect" (frag. 650): it is not for the sake of the human good, which lies beyond its power to achieve, seeing as it can end neither ignorance, nor mortality, nor the deep conflict within our nature. The "glory" of the political realm is nothing but the vain attempt to substitute 
another life, one lived in the eyes of others, for the unhappiness of our actual life (frag. 707).

For Pascal, then, man is a being with instincts for action. He has drives that point and prod him toward a certain set of goals, but he has been set loose within an environment in which all of those goals are set at an infinite distance. Weak, corrupt, and ignorant, man's one chance of gaining the human end requires a transcendent power that could transport him beyond the limits of his own horizon.

Pascal's conception of the human condition can be summarized as follows:

1. All human beings necessarily wish to be happy, and all other desires are subordinate to this wish.

2. All human beings are a mixture of a rational nature and an animal nature, each with its own principles.

3. Human happiness requires fulfilling both our rational and our animal nature and harmonizing these with each other.

4. We are incapable of fulfilling or even harmonizing the desires natural to human nature.

5. We lack the power to change the human condition so as to make it possible to fulfill the desires natural to human nature or to harmonize our two aspects.

From these premises, Pascal derives the following conclusions:

C1. Human beings are necessarily wretched and miserable beings.

$\mathrm{C} 2$. The reason why human beings are wretched and weak is that human nature has been corrupted from its original form.

C3. We are capable of no form of action that could cure or significantly ameliorate human wretchedness and weakness.

C4. Human wretchedness and weakness can therefore be cured only by receiving supernatural grace from a transcendent source, that is, God.

\section{THE MIXTURE THAT IS HUMAN NATURE: TOCQUEVILLE'S CRITIQUE OF PASCAL}

Tocqueville agrees with Pascal in conceiving of human nature as a combination of two factors (premise 2) and in thinking that happiness requires harmonizing these with each other (premise 3). He also accepts that we are not happy (conclusion C1) but seems to think it better to be content without happiness and to fight our "foolish passion" for it (Tocqueville 1985, 63). In 
accepting these, he also makes a criticism of Pascal of far-reaching significance (2.1.10, Tocqueville 2010, 781-82): according to Tocqueville, Pascal attempted to live too much in thought; his life was inhuman because it gave too little place to "the brute." We might be tempted to say that this criticism has no theoretical significance; after all, Tocqueville criticizes Pascal the man on the basis of Pascal's own principles. However, consider premise 5: does not Pascal's estimation of human power have great implications for how we think of action, which is to say, to what kind of use we may put "the brute"? The most obvious significance of our animality, in contrast to our spirituality, is embodiment: we have bodies and are therefore beings who do things in the world; we are beings who act, not merely thinkers. But what sort of action are we to engage in? Pascal's conception of politics is deeply apolitical; only private life seems to retain any true significance (frag. 650). His view of human life encourages “individualism" (2.2.2, Tocqueville 2010, 881-84). Even in the religious realm Pascal does not carve out a significant role for action. The fragments concerned with "Christian Morality" have surprisingly little to say about the type of activities Christians should engage in, and Pascal devotes remarkably little space to developing his potent metaphors of the Church as a "republic" or as "a body of thinking members" (frag. 403). Similarly, the sacramental practices he recommends unbelievers engage in (on the suppositions that "faith is catching," as Hacking [2006, 67] puts it, and that it is necessary to give "belief" the "immediacy and authority of 'sentiment" [Moriarty 2003, 156]) help prepare the body—or, as he terms it here, "the machine"-to follow the Christian way of life, but these practices are empty without grace, and they do not manifest the "greatness" that marks thought. Although Pascal asserts that "we are as much automaton as mind" (frag. 661), his thought tilts injudiciously far toward the spiritual factor.

One must be careful here. Pascal's view is not, as some might take it, that the soul is good and the body bad, but that humanity is subject to a double duality of body (or automaton) and soul (or mind), on the one hand, and nature and corruption, on the other. The mind or soul is the source of human greatness but is not thereby identified with goodness. For Augustine, whom Pascal follows closely in his theology, human corruption arises in the soul, in the sin of pride, and not in the body. The corruption of the body is the punishment of the sin of the soul (Augustine 1998, 606). The duality of mind and automaton is established in creation and would be as much a part of a perfect humanity as a fallen one. Greatness is the exclusive prerogative of the mind, or of thought. By comparison, the body is petty or base. As created, however, both are good. As fallen, both are evil. Thus, he believes that wickedness can manifest greatness, as when he says, "When wickedness has reason on its side, it becomes proud, and shows off reason in all its lustre" (frag. 458). We 
are necessarily both mind and body, and thus for Pascal salvation does not come through the mind, but through the heart (frag. 680).

Tocqueville treats these two dualities differently. Like Kierkegaard and Dostoevsky, religious thinkers influenced by Pascal, he sought a form of activity in which the two aspects of human nature, soul and body, could be harmonized and that would escape the charge of vanity. Unlike them, Tocqueville is concerned specifically with redeeming the political realm and with identifying a way that action might share in the "greatness" Pascal associated with "thought" or the "angel." According to Tocqueville, in the right conditions we are "powerful and free" and capable of engaging in action that manifests greatness in a way ruled out by Pascal's understanding of our condition. Perhaps we cannot cure the human condition; but if Tocqueville is correct, such action allows us then to significantly improve it. He is after a means not "to transcend" but "to preserve and reform this life" (Lawler 1993, 82). He rejects premise 5 , at least as it stands.

This leads Tocqueville to make modifications elsewhere. Premise 4 is modified as follows: the ultimate harmonization and correction of the human condition is impossible in the temporal realm, but action manifesting the greatness of thought does effect a partial improvement and harmonization. Tocqueville is silent concerning conclusion C2, inferring neither Pascal's Christian nor Rousseau's historical version of the "corruption" claim. Thus, the second duality disappears from view; he is less Augustinian than Pascal and less antiAugustinian than Rousseau. Tocqueville's view of conclusion C4 seems to be that if the human condition can be fundamentally transformed, it can be cured only through such a means (1.2.9, Tocqueville 2010, 482). But his modification of premise 5 leads him into a direct confrontation with conclusion C3: action cannot effect the kind of cure described in conclusion $\mathrm{C} 4$, in which the ultimate fulfillment of human desires is envisioned and the distressing conflict of angel and beast is completely overcome; it can, however, do much more to affect our condition than Pascal believed, and it is in such action that Tocqueville found the best cure for our restlessness and the fulfillment of our need for harmony between angel and beast. It may be that conclusion $\mathrm{C} 1$ is not as sure as it seems.

\section{FREE ACTION AND ACTION MANIFESTING GREATNESS}

Alongside our deplorable ignorance, our mortality, and the perpetual disturbance between the two conflicting aspects of human nature, then, we also find a fourth important part of the human condition: our capacity to engage in a form of action realizing the greatness of thought. Such action, originating 
in the categories of thought rather than through the necessities of the body, is a form of free action. Thus, for Tocqueville, human beings must be free to manifest greatness; and unless we believe ourselves free, we will not become the sort of people or engage in the sort of projects that manifest greatness.

Tocqueville's category of action manifesting greatness can be understood by examining some of his examples of it: an aristocrat's extravagant vices (2.2.11, Tocqueville 2010, 936); the making of magnificent tombs (1.1.1, Tocqueville 2010, 43); Renaissance painting (2.1.11, Tocqueville 2010, 795); the American Pilgrims' founding of a new colony where they would be free to worship (1.1.2, Tocqueville 2010, 54); the actions of the American statesman George Washington in the founding and in establishing the direction of American foreign policy, a greatness most completely expressed in his resistance to the exaggerations of popular passion (1.1.8, Tocqueville 2010, 190; 1.2.5, Tocqueville 2010, 371); and the actions of the French Revolutionary generation during the first stage of the Revolution (The Old Regime and the Revolution 1.3.8, Tocqueville 1998, 244).

Like Aristotle, Tocqueville distinguishes greatness as a quality of action from other qualities, such as goodness (Aristotle, Poetics 1450b25). Actions manifesting greatness can be admired under that category despite being either vicious or deeply problematic in other ways. Today we admire the Pyramids, the Great Wall, and other monuments raised by despotic powers despite the conditions under which they were created and even the ends they were meant to serve; Tocqueville likewise distinguishes between the question whether an action arose in thought and the question whether it arose from a thought that was true or even good.

Let's begin with Tocqueville's famous statement that what set apart the American Pilgrims who colonized New England was their aim: rather than being "forced by necessity," they had left behind relatively comfortable material and social circumstances "to obey a purely intellectual need"; they suffered the "deprivations of exile" and settled in a "rough and neglected" land that required them to exert tremendous effort, all for "the triumph of an idea" (1.1.2, Tocqueville 2010, 54). Tocqueville observes that the greatness of this action has been enough to make Plymouth Rock, an insignificant boulder, into an "object of veneration" (57). He concludes, echoing Pascal, by saying that "the power and the greatness of man lie entirely in the soul" (57).

The main elements of Tocqueville's conception of greatness-in-action appear here: (1) the action was not motivated by material necessity, or at least not directly necessitated by instinct or by material needs; (2) the action originated "in the soul," that is, in an idea or ideal that itself manifests greatness in the form of virtue, wisdom, beauty, or something similar; and (3) it required considerable effort and power or mastery to realize the idea in the world. Dif- 
ferent actions may display these qualities to varying degrees, but the most impressive human achievements, from Tocqueville's perspective, seem to need all three qualities to a high degree. (And so he might have judged the Pyramids of Giza more impressive than the Great Wall because they were not constructed to fulfill a natural necessity such as defense.)

The other paradigms of greatness-in-action cited by Tocqueville correspond to the example of the Pilgrims, manifesting all three of these qualities as well. In each case, the action does not aim at meeting a material need or natural necessity. The construction of tombs, the production of fine art, and the pursuit of "liberty, equality, and fraternity" do not fill the stomach or clothe the body. Further, each arises from an idea or ideal having its origin in thought. Modern painters, such as Jacques-Louis David, are exact anatomists, but their painting does not display greatness; they "copy small objects that have only too many originals in nature." Renaissance painters, on the contrary, "looked above themselves" for "great subjects"; Raphael "sought something better than nature" for his art, and rather than merely providing "an exact portrait of man," he "gave us a glimpse of divinity in his works" (2.1.11, Tocqueville $2010,795)$. Finally, all these examples require great mastery to be achieved. None could be executed without overcoming significant difficulties and without showing extraordinary character and personal qualities, above all, displaying mastery-a mastery of the material environment that allows the actor or actors to bridge the gap between the realm of thought, where the idea or ideal arose, and the realm of the body, where this idea is now to be realized and achieved. As Pascal wrote, "only mastery and control create glory" (frag. 648).

Actions manifesting greatness are, like humanity itself, mixed. Their peculiar mixture can be understood by comparison with two different sorts of mixed actions. Tocqueville considers the Pilgrims' actions to have manifested greatness. Their lofty goal was reinforced by the nature of the efforts required in colonizing New England: the difficulty of settling in the rough landscape, the requirement that life must struggle with death, meant that the settlers' efforts to meet their material needs always required the soul's involvement as well. They constantly had to develop and exercise virtues and qualities belonging to the soul in order to successfully transform their surroundings into a livable environment. Thus, not only did they set out with the object of realizing an idea, but even their material needs served to reinforce their "soulish" orientation, while preventing them from becoming as excessively soulish as Pascal, with whom they shared theological kinship.

But if the Pilgrims were so challenged by their environment as to require the constant development and use of the powers of the soul by natural necessity, as it were, the Americans of Tocqueville's time presented a different aspect. 
They too were engaged in constant practical activity - the unending pursuit of greater wealth. But what was the end of this pursuit? What pressure led to this constant activity, if the natural environment was no longer so threatening? The American social state is democratic, which is to say, it is marked by widespread socioeconomic equality: society is filled with many weak individuals whose fortunes vary constantly rather than a few classes whose power remains constant from generation to generation. Thus, material goods are available to anyone, but only with effort, and these are never secure. This uncertainty and the general enjoyment of "mediocre fortunes," coupled with the "natural and instinctive taste" for material well-being, produce desire and fear: desire to possess greater material wealth and the fear of losing what one has $(2.2 .10$, Tocqueville 2010, 931, 933). This gives the passion for material gain a particularly powerful grasp on the soul (931).

Restlessness, however, is not the effect simply of the uncertainty attached to Americans' material possessions. Americans' devotion to material well-being starves the soul, so that its needs are not met (2.2.12, Tocqueville 2010, 940). The pursuit of material wealth may "distract it from itself" but cannot prevent it from becoming "bored, restless, and agitated" (940). In a few individuals, this leads to the formation of "bizarre sects" and "religious madness" (940); in these instances, the angel strives to break free from the brute altogether and, not knowing itself or its limits, runs "beyond the limits of common sense" (941).

The starving of the soul produces other effects in the greater population. "The man who has confined his heart solely to the goods of this world" (2.2.13, Tocqueville 2010, 944) is driven into a kind of irrationality. Knowing that he has only "a limited time" (944) to enjoy goods "so precious, so incomplete, and so fleeting" (2.2.10, Tocqueville 2010, 933), he is "goaded" by the knowledge that life is running out and that death will cut short his enjoyment of these transient goods (2.2.13, Tocqueville 2010, 944): “at every instant he is afraid of ceasing to live before enjoying them" (943). In fact, despite the American's vaunted philosophy of "interest well-understood," he seems to regularly miscalculate: despite constant anxiety about spending more effort in obtaining a good than its enjoyment is worth (945), he is caught up in "useless pursuit" that does not end in the enjoyment of his goods, or in "felicity," but in the intervention of "death" (944). For the average individual in a democratic society, then, the starving of the soul produces a kind of heightened material activity that is driven on by the fear of death-not of death per se, but of death's curtailing of enjoyment-which is, when strictly examined, irrational in itself and productive of "melancholy" and "disgust with life" (946). 
What is the difference between these cases? In both, the American is put to constant labor to achieve the needs of the body; yet in one, this yields the improvement of the powers of the soul, and in the other, their impoverishment. The early Americans, we note, enjoyed a more aristocratic social state, the later Americans a more democratic one; religion and the conviction that humanity includes "a non-material and immortal principle" were more natural to the former than the latter $(2.2 .15$, Tocqueville 2010, 958). Such convictions must be "protected carefully as the most precious heritage of aristocratic centuries" (958), and this is why Tocqueville shortly argues that democratic legislators must, to the greatest extent possible, strive to inculcate "the taste for the infinite, the sentiment of the grand, and the love for non-material pleasures" (957). The lofty and austere character of a Washington presents such an example, but the conditions necessary for preparing such individuals have dwindled in subsequent generations. The early Americans, the Pilgrims, had an ultimate goal rooted in the soul: the establishment of an idea. The more they had to strive with their environment to realize this idea, the more it supported their endeavor by strengthening their character. But for the later Americans, these ends appear insignificant, and their constant pursuit of material goods drowns the soul in narrow and petty concerns.

One should not miss the very Pascalian use that Tocqueville makes of the fear of death here. That fear is closely associated with the pursuit of material goods, which, by their nature, can be enjoyed only in this life. The Americans Tocqueville describes seem trapped in a vicious cycle: the more they pursue these goods, the more uneasiness they experience and the more frantically they need to pursue the goods, precisely because of the latter's instability and transitory nature, so that finally the Americans live entirely in their pursuit and, to the extent that they enjoy what they possess, seem to do so by accident. They are actively increasing the discordance between the two elements of human nature in themselves and intensifying the ills of the human condition by increasing the fearfulness of death.

This explains Tocqueville's severe language regarding those who teach materialism. Because materialism encourages, and would even justify, Americans in this behavior, we should "consider the men who profess [these harmful theories] as the natural enemies of the people" (2.2.15, Tocqueville 2010, 957). We cannot know the answers to the ultimate questions, such as whether materialism is true, but Tocqueville thinks that we can and do know what the results are of following that doctrine. Because Tocqueville's adherence to several key features of Pascal's conception of the human condition is often not apparent, his condemnation of materialism can surprise the reader. Tocqueville sees the propagation of materialism as increasing the inherent misery of 
the human condition and driving us away from what is "great" and worthwhile in human life.

Since a democratic social state is conducive to materialism and hostile to belief in any kind of spiritual reality, the fate of democratic peoples-their ability to respond appropriately to the human condition and to engage in activities manifesting greatness-appears to hinge on whether they can preserve their sources of spiritual belief. This is why Tocqueville recommends that democratic legislators pay careful attention to the preservation of religion: "it is when religion is not speaking about liberty that it best teaches Americans the art of being free" (1.2.9, Tocqueville 2010, 472), he says, and we must combine this with his statement that "it is necessary that all those who are interested in the future of democratic societies unite, and that all in concert make continual efforts to spread within these societies the taste for the infinite, the sentiment for the grand and the love for non-material pleasures" (2.2.15, Tocqueville 2010, 957). This is achieved, above all, by combating materialism and preserving any "belief in a non-material and immortal principle" (958). We must preserve the possibility of action like that undertaken by the Pilgrims, rather than limiting ourselves to the pursuit of materialistic consumption.

We are now in a position to better understand why greatness-in-action forms Tocqueville's great exception to Pascal's picture. He believes that actions and activities that manifest greatness somehow ameliorate our condition. But why?

\section{THE AMELIORATIVE POWER OF GREATNESS-IN-ACTION}

Tocqueville agrees with Pascal that our existence is marked by severe ills and that we are unable to fundamentally transform our condition to avoid them. However, he parts from Pascal in believing that there are ways of significantly improving our condition, through engaging in action that manifests greatness. The question is, why believe that engaging in such action alters our condition?

Tocqueville never wears his theories on his sleeve. This is why his philosophical sophistication has been so underestimated (as noted, e.g., in Lawler 1993, 98); he leaves the work of excavation and reconstruction to his reader. Let us, then, put things together. The body has needs and desires intrinsic to it; the soul also has its needs and desires. In pursuing material goods we generally serve the body; in pursuing spiritual goods we serve the soul. When the soul is starved in the pursuit of material goods, its uneasiness gives a frantic character to the pursuit of material well-being. On the other hand, the body is neglected for the pursuit of pure spiritual goods. The body suffers, and a Pascal wears 
out his body too soon, so that he dies "of old age before reaching forty years of age" (2.1.10, Tocqueville 2010, 782). But there are activities in which the two of these come together and, to some extent, harmonize with one another: activities arising in the soul, in a great idea or ideal of some kind, and achieved through mastery exercised in the material realm. These aim at a goal that combines physical and spiritual qualities and, in their greatness, achieve a lasting existence that endures beyond the life of the actor. Those who engage in these activities also acquire a kind of knowledge- not the knowledge that consists of abstract, general concepts, of which Tocqueville is so dismissive, and not the knowledge of those ultimate truths that Tocqueville despaired of ever finding, but a knowledge rooted in things and in action, a knowledge that is both precise and practical and related to matters of importance.

Let's begin with the question of harmonizing the two aspects of human nature. What is it about activities manifesting greatness that brings the elements of human nature together? It is not that activities manifesting greatness manage to meet both types of needs at once: painting a great masterpiece is no means to care for the body. Very few activities manifesting greatness would have the accidental quality of also caring for the body's needs. Constructing a great work of architecture or founding a republic that will endure the ages might be actions of this type: although aiming to realize an idea, they also do something for the body. But this is not generally the case, and Tocqueville attaches little importance to such coincidences, so we need to consider a different sort of harmonizing that occurs in these activities.

Greatness-in-action harmonizes the soul and the body, the spiritual and physical aspects of ourselves, by embodying an idea or making the ideal real, through the use of the body. Accomplishing this task requires great mastery of the physical realm in which the work is to be accomplished-a practical, embodied knowledge of the material realm in which the idea is to be realized. Exercising this mastery is an affair of the body, involving it in the constant pursuit of the ideal put before it by the soul. In pursuing this ideal, the body is ennobled and participates in greatness insofar as it realizes the achievement of its sublime goal, whereas the body is despised and negated by philosophers and contemplatives who seek greatness in pursuing answers to the eternal questions, in contemplation, or in other purely spiritual activities, so that it is finally "worn out" by someone like Pascal who accomplishes this too completely. In the effort to embody the ideal, the body is an active participant that, through the exercise of mastery, is constantly harmonized with the soul in the activity of embodiment. In these activities we are whole.

Soul and body are therefore harmonized in the activity itself in which each pursues the same end. But does such activity really do nothing to satisfy the needs and desires of our bodily aspect, except by accident? The most funda- 
mental of the body's needs is the instinctive aversion to death; it is this instinct that is, ironically, frustrated the most when a person is wholly devoted to pursuing material goods, since these are only good in being enjoyed, and enjoyment ends when the body dies and can only begin when pursuit ceases. The stationary peasant gets more enjoyment from the little he has than the restless American who devotes himself to always obtaining more (2.2.13, Tocqueville 2010, 942-43). Not only the activity itself, but also the result of greatness-in-action ameliorates the human condition by leaving behind either a great product or the memory of something great. When someone embodies the ideal in something that exists here and now, in some monument, or institution, or event that will be remembered, the person leaves behind something that will endure beyond death. Tocqueville agrees with Pascal that ultimately we lack the power to overcome death, remarking that, "of all the works of man, the most durable is still the one that best recounts his nothingness and woes!"- that is, the tombs that we build for the dead, which sometimes endure long beyond the memory of the people who made them (1.1.1, Tocqueville 2010, 43). The power to abolish death transcends human capacities. Within the circumscribed horizon of what lies within our power, however, it is possible to achieve something significant and worthwhile that will endure beyond us, an aspect of glory that escaped Pascal.

In such action we also escape the fundamental ignorance that marks our condition. We resort to general ideas in our inability to properly grasp and understand "the immensity of details" involved in attempting "to examine and to judge individually all the particular cases" connected to a topic (2.1.3, Tocqueville 2010, 726). Our "imperfect, but necessary procedure" is to give similar cases the same name, and therefore to treat distinct but analogous beings, facts, and rules as if they were exactly the same (727). But when it comes to action, the matter is different; when it comes to what people deal with "everyday" and "in a practical way," they must "enter into details" and acquire a very "deep knowledge" and "infinite skill” (2.1.4, Tocqueville 2010, $739 ; 1.2 .11$, Tocqueville 2010, 174). This obtains great significance when it comes to political matters: a people that "has only been able to think about the best way to conduct politics" will necessarily be very poor at it (2.1.4, Tocqueville 2010, 738). One that "has always run public affairs by themselves" will, on the contrary, not be overly taken up by theories that only approximate reality (The Old Regime and the Revolution 1.3.1, Tocqueville 1998, 201; Democracy in America 2.1.4, Tocqueville 2010, 739). Such a people will instead have a grasp of the elements of politics rooted in experience with the matter itself.

Can such knowledge compensate for our ignorance of fundamental principles? To be sure, it is hard to see how a fine and exact knowledge of wheat 
prices would do so, but should we say the same of the knowledge related to greatness-in-action? If statesmanship, for example, manifests greatness in it, then must we not attribute added importance to knowledge related to statesmanship, above all to the kind that is well acquainted with action itself, and not just the theoretical knowledge of it that Tocqueville criticized Diderot for (The Old Regime and the Revolution 1.3.2, Tocqueville 1998, 206)? And likewise to the knowledge related to these other kinds of action that manifest greatness? Since we know best what we are most frequently and actively engaged with, this knowledge will not suffer from the looseness and falsifying abstraction that afflicts so much of our theoretical knowledge; and since it relates to something that is great, sublime, or otherwise significant, this knowledge will not be something petty. Just as the endurance of greatness-inaction falls short of immortality but greatly exceeds that of purely material goods, so too the knowledge of matters related to greatness-in-action falls short of the knowledge of first principles we desire but cannot have, but it greatly exceeds the other kinds of knowledge we can obtain-it exceeds our theoretical knowledge by being true and more precise, and it exceeds our other practical knowledge by relating to matters with greater significance and importance.

In this way, then, we can see how Tocqueville could conclude that engaging in action that manifests greatness can indeed ameliorate the human condition. Such action strikes at each of the particular woes associated with our condition and, although not completely victorious in vanquishing them, establishes a rampart against them and secures a place within which human beings can become more whole and, to some extent, triumphant over our ignorance and mortality.

It also helps us to understand why we should regard liberty as particularly important—and why liberty cannot be identified either with simply providing individuals with security in their private pursuits (as Aron $[1965,190]$ mistakenly concludes) or with the collective actions of a large mass of individuals. Liberty as Tocqueville understands it secures the possibility of individuals freely coming together in action (see Boesche 1987, 154-55). Some kinds of greatness-in-action can be achieved by a single individual or by a few friends. Great goals, however, frequently require the cooperation of many individuals acting together. Liberty as Tocqueville understands it—a liberty that provides individuals with institutional and social contexts in which to freely initiate and freely participate in action together with others-does not guarantee that it will be used for the sake of great and significant goals. Such liberty is, however, frequently one of its necessary conditions. A liberty that secures only the pursuit of individual interests, or a liberty that only allows individuals to come together for the sake of electing a national leader, would never suffice to secure this possibility for individuals. Besides threatening to produce conditions fa- 
vorable to tyranny, such arrangements are objectionable in that each throws individuals back upon themselves and divorces them from a context in which they could participate in action that manifests greatness, so that they "[fall] gradually below the level of humanity" (2.4.6, Tocqueville 2010, 1259).

Without denying Pascal's transcendent ultimate solution to the ills of human existence, then, Tocqueville provides a this-worldly response to our condition, a way of confronting it in the here and now. His political solution is imperfect; politics is still partially a diversion (Lawler 1993, 118). In a certain way, tombs, which testify to our "nothingness," are a symbol for all types of greatness-in-action. Nonetheless, if Tocqueville is correct, then we may cede much to Pascal without ceding all. It may be true that humanity is afflicted by significant, even crippling, ills of ignorance, mortality, and disorder, and that the only cure for these lies at an infinite distance from us, beyond peaks we can never scale and a transcendent horizon we can never cross. But within the domain that is within our power there are palliatives available and modes of existence that manifest some of the grandeur that Pascal argued was lost in Adam, including liberty and political action-not beyond the unclimbable peaks but among the foothills whose ascent is, sometimes, within our power.

\section{REFERENCES}

Aron, Raymond. 1965. Main Currents in Sociological Thought. Vol. I. Translated by Richard Howard and Helen Weaver. New York: Basic Books.

Augustine. 1998. The City of God against the Pagans. New York: Cambridge University Press.

Boesche, Roger. 1987. The Strange Liberalism of Alexis de Tocqueville. Ithaca, NY: Cornell University Press.

Corral, Diez del. 1965. "Tocqueville et Pascal.” Revue des Travaux de l'Academie des Sciences Morales et Politiques.

Dostoevsky, Fyodor. 1994. The Karamazov Brothers. Translated by Ignat Avsey. Oxford: Oxford University Press.

Dreyfus, Hubert. 2012. “'What a Monster Then Is Man': Pascal and Kierkegaard on Being a Contradictory Self and What to Do about It." In The Cambridge Companion to Existentialism, ed. Steven Crowell, 96-110. Cambridge: Cambridge University Press.

Hacking, Ian. 2006. The Emergence of Probability. 2nd ed. New York: Cambridge University Press.

Jech, Alexander. 2013. “'Man Simply’: Excavating Tocqueville’s Conception of Human Nature." Perspectives on Political Science 42 (2): 84-93.

Khalfa, Jean. 2003. "Pascal's Theory of Knowledge." In The Cambridge Companion to Pascal, ed. Nicholas Hammond, 122-43. New York: Cambridge University Press.

Kolakowski, Leszek. 1995. God Owes Us Nothing. Chicago: University of Chicago Press.

Lamberti, Jean-Claude. 1989. Tocqueville and the Two Democracies. Cambridge, MA: Harvard University Press. 
Lawler, Peter Augustine. 1993. The Restless Mind: Alexis de Tocqueville on the Origin and Perpetuation of Human Liberty. Lanham, MD: Rowman \& Littlefield.

Moriarty, Michael. 2003. "Grace and Religious Belief in Pascal." In The Cambridge Companion to Pascal, ed. Nicholas Hammond, 144-61. New York: Cambridge University Press.

Nietzsche, Friedrich. 1996. Selected Letters of Friedrich Nietzsche. Edited by Christopher Middleton. Translated by Christopher Middleton. Indianapolis: Hackett.

Pascal, Blaise. 1995. Pensées and Other Writings. Translated by Honor Levi. Oxford: Oxford University Press.

Tocqueville, Alexis de. 1985. Selected Letters on Politics and Society. Edited by Roger Boesche. Translated by Roger James Toupin and Roger Boesche. Berkeley: University of California Press.

1998. The Old Regime and the Revolution. Vol. 1. Edited by François Furet and Françoise Mélonio. Translated by Alan S. Kahan. Chicago: University of Chicago Press.

2010. Democracy in America. Bilingual ed. Edited by Eduardo Nolla. Translated by James Schliefer. 4 vols. Indianapolis: Liberty Fund.

Zuckert, Michael. 1993. “On Social State.” In Tocqueville's Defense of Human Liberty, ed. Peter Augustine Lawler. New York: Garland. 